\title{
THE UNITY AND DIVERSITY OF GOD'S COVENANTS
}

Roger T. Beckwith

It is now thirty three years since the late Professor John Murray gave his Tyndale Biblical Theology Lecture 'The Covenant of Grace', which was published by the Tyndale Press the following year, 1954. In a characteristically informative and thoughtful way, Murray briefly traced the development of covenant theology in Reformed circles from its pregnant beginnings in the writings of Johann Heinrich Bullinger and especially in book 2 of John Calvin's Institutes, through the careful elaboration of the concept in the Dutch federal theologians of the seventeenth century (from their pioneer Johannes Cocceius [Johann Koch] to their consummator Herman Witsius), ${ }^{1}$ and up to the expositions by his immediate predecessors, G. C. Aalders ${ }^{2}$ and Geerhardus Vos. ${ }^{3}$ He went on to examine the meaning of the term 'covenant' and its use in the Bible, taking in turn God's covenants with Noah, with Abraham, with Israel, with David, and the New Covenant. Murray affirmed, with all his predecessors, that the covenant of grace is essentially one in all its different dispensations, being centred on God's promise 'T will be your God and ye shall be my people' (Lv. 26:12 etc.), but denied, with Aalders and Vos, that such covenants are mutual compacts; rather, he held, they are one-sided sovereign grants, made by the gracious initiative of God.

Since the time of Murray's lecture, the subject of God's covenants has attracted an unusual amount of attention, particularly from Old Testament scholars. In 1961 and 1967 the two volumes of the English translation of Walther Eichrodt's Theology of the Old Testament appeared. ${ }^{4}$ The first German

'See esp. H. Witsius, The Oeconomy of the Covenants between God and Man ([1685] ET; London, Dilly 1775).

2Het Verbond Gods (Kampen, Kok 1939)

3 See his Biblical Theology (Grand Rapids, Eerdmans 1948), and the papers now collected in Redemptive History and Biblical Interpretation, ed. R. B. Gaffin Jr. (Phillipsburg, Presbyterian \& Reformed 1980).

4 London, SCM. 
edition of this work had been published as early as 1933 , and subsequent writing had not significantly altered the author's ideas, but it is interesting among contemporary continental theologies of the Old Testament as the one which attempted to organize all its material under the concept of covenant, as being an original and basic element in Israel's religion. A reassertion of the opposite view, previously championed by Julius Wellhausen, that the covenant idea was a late development in Israel's religious thinking, was issued in 1969: this was the Bundestheologie im Alten Testament of Lothar Perlitt. ${ }^{5} \mathrm{He}$ holds that the covenant idea was unknown even to the eighthcentury prophets, and first appears in Deuteronomy, to which of course a late date is assigned. Essentially the same view has now been adopted by E. W. Nicholson in his book God and his People: Covenant and Theology in the Old Testament, just published. 6 He holds that the conception of a covenant between God and Israel first came to prominence in the later monarchy, and is of theological rather than historical importance.

Assertions of this sort can now only be made in face of the most original contribution to covenant theology in the last few decades, namely, the parallel drawn between the biblical covenant and the ancient Near-Eastern treaty, which Nicholson judges to be simply a 'blind alley'.7 Attention was first drawn to this parallel by G. E. Mendenhall in 1954, in his article 'Covenant Forms in Israelite Tradition', 8 and study of the issue was pursued further by many others, including J. A. Thompson, ${ }^{9}$ D. J. McCarthy, ${ }^{10}$ M. G. Kline, ${ }^{11}$ and K. A. Kitchen. ${ }^{12}$

The closest extant parallels are provided by Hittite

5 Wissenschaftliche Monographien zum Alten und Neuen Testament 36 (Neukirchen-Vluyn, Neukirchener Verlag).

6Oxford, Clarendon Press 1986.

7 God and his People vi; cf. 81.

8 BA 17 (1954) 49-76.

9 In his 1963 Tyndale Lecture in Biblical Archaeology, The Ancient Near Eastern Treaties and the Old Testament (London, Tyndale Press 1964).

10 Treaty and Covenant (2nd edn., Analecta Biblica 21A, Rome, Pontifical Biblical Institute 1978).

11 Treaty of the Great King (Grand Rapids, Eerdmans 1963); The Structure of Biblical Authority (Grand Rapids, Eerdmans 1972) and other publications.

12 Ancient Orient and Old Testament (London, Tyndale 1966) 90-102. 
treaties between overlords and vassal kings dating from the latter part of the second millennium $\mathrm{BC}$, when set alongside what is, strictly speaking, God's third covenant with Israel, found in the book of Deuteronomy (the earlier two coming in Ex. 24 and Ex. 34). As in Deuteronomy, the Hittite treaty was unilaterally imposed by the sovereign and could include a preamble, a historical resumé, charges to faithfulness, injuctions to specific duties, the invocation of heaven and earth as witnesses, curses and blessings, and provision for the covenant documents to be laid up in a sanctuary, from which they were periodically to be brought out and publicly read. The Hittite treaty might also include a religious ceremony to ratify it, and oaths by the vassal. These are not paralleled in Deuteronomy, where the oaths are sworn by God not Israel (Dt. 29:12, 14), and where no religious ceremony on the occasion is described, though a religious ceremony inaugurates some of God's other covenants, notably that with Abraham in Gn. 15 and the first covenant with Israel at Sinai in Ex. 24. Despite these two differences, and despite the fact that God's covenants with Israel were made with a nation rather than with a vassal king, the parallels are so numerous and striking that it is difficult to think that some such type of human treaty was not the convention which God adapted to his purposes in Deuteronomy, and which virtually gives shape to the whole book. ${ }^{13}$ This fact has bearings upon the date of Deuteronomy and the historicity of its contents, as Kline persuasively argues, and the least it shows is that some of the covenant material in the Old Testament literature may very well be extremely early. ${ }^{14}$

Of quite another kind is the book The Consequences of the Covenant by G. W. Buchanan, published in $1970 .{ }^{15}$ This carries forward some of the themes of Eichrodt's book, and some others, into the period of the New Testament and contemporary Judaism. These themes are the theology of conquest, the

13 Cf. P. C. Craigie The Book of Deuteronomy (NICOT; Grand Rapids, Eerdmans 1976) 23-4, "This treaty form ... finds striking expression in the book of Deuteronomy as a whole'.

14 Space precludes discussion of M. Weinfeld's hypothesis that Deuteronomy is in fact a seventh century document which reflects the form of first millennium treaties (Deuteronomy and the Deuteronomic School [Oxford, Clarendon 1972], especially 59-157). For a critique of Weinfeld's monograph see R. B. Dillard's review (WT] 36 [1973-4] 263-9).

15 Supplements to Novum Testamentum 20 (Leiden, Brill). 
kingdom of God, the land of the conquest, life under the covenant, covenantal asceticism, covenantal provisions for forgiveness and reconciliation, covenantal sectarianism, and covenantal practices.

Finally, three weighty works of recent date must be mentioned: The Christ of the Covenants by $O$. Palmer Robertson, ${ }^{16}$ Covenant and Creation: an Old Testament Covenantal Theology by W. J. Dumbrell, ${ }^{17}$ and The Covenants of Promise: a Theology of the Old Testament Covenants by T. E. McComiskey. ${ }^{18}$ These three studies are all in the same Reformed tradition as Murray's lecture of 1953. Neither of the latter two, which were published only a year apart, refers to the other, or comments on each other's thesis, so evidently they were produced quite separately. Robertson's book was only drawn to the writer's attention after this lecture was delivered, but he has been grateful to find support there for some of his main contentions.

\section{THE MEANING OF THE TERM 'COVENANT'}

We must pass on now from the literature on which we will be able to draw, to the subject matter of this paper. The Hebrew term for covenant, commonly connected with the Middle Assyrian noun biritu, meaning 'bond' or 'fetter'. As- Dumbrell remarks, this is supported by the fact that, in contexts of the Old Testament where relationships are established or confirmed, the word 'seems usually to carry with it the note of obligation, whatever else may be implied at the same time'. ${ }^{19}$ Usage, however, tells us rather more than etymology. In Old Testament usage, a פריז means a league of friendship, either between man and man or between God and man, solemnly inaugurated, either by words alone or by words and symbolical ceremonies, in which obligations are undertaken on one or both sides. The obligations are often accompanied by an oath, and have the character of solemn promises.

In the New Testament, the corresponding word is

${ }^{16}$ Grand Rapids, Baker 1980.

17 Exeter, Paternoster 1984.

18 Grand Rapids, Baker 1985.

19 Covenant and Creation 16. 


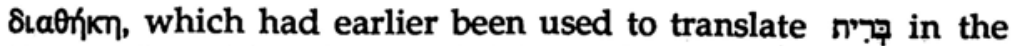
Septuagint. The choice of this rendering is illuminatingly discussed by Geerhardus Vos. He writes:

With the Greek word 'diatheke' the matter stands somewhat differently. The rendering of berith by this amounted to a translation-compromise. Diatheke at the time when the Septuagint and the New Testament came into existence not only could mean 'testament,' but such was the current meaning of the word. It was, to be sure, not its original meaning. The original sense was quite generic, viz., 'a disposition that some one made for himsel'' (from the middle form of the verb diatithemi ). The legal usage, however, referring it to a testimentary [sic] disposition had monopolized the word. Hence the difficulty with which the Greek translators found themselves confronted. In making their choice of a suitable rendering for berith they took a word to whose meaning of 'last will' nothing in the Hebrew Bible corresponded. And not only this, the word chosen seemed to connote the very opposite of what the Hebrew berith stood for. If the latter expressed unchangeableness, testament seemed to call up the idea of changeableness at least till the moment when the testator dies. Moreover the very term testament suggests the death of the one who makes it, and this must have appeared to render it unsuitable for designating something into which God enters. When notwithstanding all these difficulties, they chose 'diatheke,' weighty reasons must have determined them. The principal reason seems to have been that there was a far more fundamental objection to the one other word that might have been adopted, the word 'syntheke'. This word suggests strongly by its very form the idea of coequality and partnership between the persons entering into the arrangement, a stress quite in harmony to [sic] the genius of Hellenic religiosity. The translators felt this to be out of keeping with the tenor of the Old Testament Scriptures, in which the supremacy and monergism of God are emphasized. So, in order to avoid the misunderstanding, they preferred to put up with the inconveniences attaching to the word 'diatheke'. On closer reflection these were not insurmountable. Though diatheke meant currently last will,' the original generic sense of 'disposition for one's self' cannot have been entirely forgotten even in their day. The etymology of the word was too perspicuous for that. They felt that diatheke suggested a sovereign disposition, not always of the nature of a last will, and repristinated this ancient signification. And in this way they not merely overcame an obstacle; they also registered the positive gain of being able to reproduce a most important element in the Old Testament consciousness of religion. The difficulty arising from the fact of God's not being subject to death is a difficulty only from the standpoint of Roman law. The Roman-law testament actually is not in force except where death has taken place, cpr. Heb. 9:16. There existed, however, in those times a different type of testament, that of Graeco-Syrian law. This kind of testament had no necessary association with the death of the testator. It could be made and solemnly sanctioned during his life-time, and in certain of its provisions go into immediate effect. The other objection arising from the mutability of the Roman-law 
testament fell away likewise under this other conception. For not only was the changeability foreign to it; on the contrary, the opposite idea of unchangeableness entered in strongly (cpr. Gal. 3:15).

From the Septuagint the word 'diatheke' passed over into the New Testament. The question has long been under debate whether here it should be rendered by 'covenant or 'testament.' The A. V. in as many as 14 instances translates diatheke by 'testament,' in all other cases by 'covenant.' The R. V. has greatly modified this tradition. In every passage, except Heb. 9:16, where the statement allows no escape from 'testament,' it has substituted 'covenant' for the 'testament' of the A. V. In all probability an exception ought likewise to have been made for Gal. 3:15, where, if not the explicit statement of Paul, at least the connection leads us to think of 'testament.' The Revisers were obviously guided in this matter by the desire to assimilate as much as possible the modes of statement in the O. T. and those in the N. T. This was in itself a laudable desire, but it seems that in certain cases it prevented due consideration of the exegetical requirements. 20

\section{THE IMPORTANCE OF THE COVENANT IDEA}

Ever since the second century of the Christian era, the church has consistently called the two parts of its sacred literature the Old and New Testaments, or Covenants. This indicates the controlling importance in biblical theology which the covenant idea has always been considered to possess, and not simply since the Reformation. If we investigate the actual occurrence of the word 'covenant', we find that it occurs in 26 of the 39 Old Testament books, in some of them very frequently, and that the 13 in which it does not occur are all of them short books. ${ }^{21}$ In the New Testament the word is used less frequently, but it occurs in Matthew, Mark, Luke and Acts, five of the Pauline epistles, Hebrews and Revelation: it is absent from the Gospel of John and the Catholic Epistles. ${ }^{2}$ However, the Old Testament is the common property of the New Testament writers, and the term is sufficiently prevalent to indicate a general biblical concept. No books of the Bible could be described as noncovenantal, still less anti-covenantal, nor does there seem to be

20 Biblical Theology 33-5.

21 In three of the 26 books (Job, Proverbs and Amos), the word does not refer to covenants between God and man but only to human covenants.

22 The Catholic Epistles are all, of course, fairly short books. The absence of the word from John's Gospel is sufficiently explained by his omission of the institution narrative from his account of the Last Supper, which is the only place where it is used in Mathew or Mark. 
any significant variation in the covenant theology of different books. The term occurs from one end of the Bible to the other, first in Genesis 6 and lastly in Revelation 11, and though it does not occur in the creation narrative or before the time of Noah, this may only be because the covenant with Noah was a new beginning for creation, after the destruction of the first world through sin. ${ }^{23}$ God's merciful covenants presuppose creation and sin, but the consummation of his purposes of mercy will also be the consummation of creation in the new heavens and the new earth, and the total obliteration of $\sin$ in the city where nothing unclean can enter (Rev. 21:1, 27).

With this exception then, the whole course of biblical history and biblical theology is covered by God's covenants; and when one considers how important the terms of some of those covenants are (one of them commanding the whole Mosaic Law; others of them promising the maintenance of the whole course of nature, or the formation of the nation of Israel, with an exodus from bondage to possess its own land, or the kingdom of God, exercised through the son of David, or the knowledge of God, forgiveness and a new heart for all God's people), the significance of the teaching about covenants becomes even more apparent. It seems undeniable, on the whole, that covenant is a proper organizing concept of great value in the study of biblical theology, even though it may not be unique in this respect.

23 The attempt to carry the covenant idea back to creation and indeed back into eternity, by claiming that there was a covenant of works between God and Adam (cf. The Westminster Confession of Faith [1647] 19:1 Deus Adamo legem dedit ut foedus operum ....), and a covenant to redeem mankind between God the Father and God the Son (cf. C. Hodge, Systematic Theology vol. 2 [London, Thomas Nelson 1875] 359-61) is too speculative. The former concept extends the term 'covenant' to a unique relationship in the age of innocence, relying on a doubtful interpretation of Hos. 6:7; and the latter concept extends the term to a relationship still more remote from what the Bible calls covenants, relying on equally doubtful interpretations of Lk. 22:29 and Gal. 3:16f. Dumbrell (Covenant and (reation), following Robertson (Christ of the Covenants), sees a covenant instead in $\mathrm{Gn}$. 1, brought about by the fact of creation, and afterwards confirmed by the covenant with Noah. This again would be a covenant made before the fall, and the exegetical basis for it is uncertain. 'Establish my covenant' (Gn. 6:18; 9:9, 17) does not necessarily mean the confirming of a pre-existing covenant, as is shown by Ex. 6:4; and 'my covenant of day and night' (Je. 33:20, 25) may simply be that with Noah (cf. Gn. 8:22). A recent advocate of the idea of the eternal covenant between God the Father and God the Son is Karl Barth (Church Dogmatics 2:2 [ET; Edinburgh, T. \& T. Clark 1957]). An accessible exposition and critique of Barth's concept of covenant is to be found in C. Brown, Karl Barth and the Christian Message (London, Tyndale 1967) 100-39. 


\section{THE NUMBER OF GOD'S COVENANTS}

The covenants recorded under that name in the Bible are extremely numerous. Some of them are covenants between people, each person undertaking to act in a friendly way to the other (for example, the covenant between Abraham and Abimelech, Gn. 26; between Jacob and Laban, Gn. 31; between Jonathan and David, I Sa. 18:1-4; and the marriage covenant, Pr. 2:17; Mal. 2:14). Others of them are again between people, but undertaking jointly to serve the Lord (for example, the covenant of Joshua and Israel, Jos. 24:25; the covenant of Josiah and his subjects, $2 \mathrm{Ki}$. 23:3; and the covenant of Zedekiah and the men of Jerusalem, Je. 34:8-22). ${ }^{24}$ In either case, it may be made in the presence of the Lord (Jos. 24:1; I Sa. 23:18; 2 Ki. 23:3; Je. 34:18), God may be invoked as witness ( $\mathrm{Gn}$. 31:50), and the covenant may be described as a 'covenant of the Lord' or 'of God' (I Sa. 20:8; Pr. 2:17; cf. Ezk. 17:19) although the Lord is not, strictly speaking, one of the covenanting parties. It is noteworthy that the same parties may make repeated covenants with each other: Jonathan and David make three, the first in I Sa. 18:3 (cf. 20:8), when their friendship begins, the second in I Sa. 20:16f., when David is being pursued by Saul, and the third in I Sa. 23:18, when they are parting for the last time.

Though the Lord has a certain role in human covenants, he is much more directly involved when he himself becomes one of the covenanting parties. Such covenants, as Murray stressed in his Tyndale lecture, are regularly initiated from the divine side, but (what he did not stress) they are also many in number. Besides God's covenants with Noah, with Abraham, with Israel at Sinai, with Dayid and the New Covenant, which Murray listed, there are also his covenants with Phinehas, granting him a permanent priesthood (Nu. 25:10-13; cf. Je. 33:21f.), with Aaron, granting him the priestly perquisites (Nu. 18:8-20; cf. Ne. 13:29; Mal. 2:1-9), and two other covenants with Israel, besides that of Ex. 24: the covenant of Ex. 34, after the sin with the golden calf, and the covenant of Dt. 29-30, after the recapitulation of the Law in the land of Moab, on the eve of entering the Promised Land. In each of these cases covenanting language is used, ${ }^{25}$ and if one

24 When men are occasionally said to make a covenant with the Lord, rather than the other way round, this is perhaps what is meant. Examples are $2 \mathrm{Ch}$. 29:10; Era. 10:3; Ps. 50:5.

25 I.e. 'make (mo literally cut) a covenant' or 'give (jog) a covenant'. A third 
adds to these the covenant with Abraham and his seed, and the New Covenant, which is likewise said to be 'with the house of Israel and the house of Judah' (Je. 31:31), there is a total of five covenants between God and Israel. As Paul puts it, Israel has had the privilege of 'the covenants' (Rom. 9:4), while the Gentiles have been 'strangers from the covenants of the promise' (Eph. 2:12).

As we noted earlier, it has been customary in Reformed federal theology, right from the time of Bullinger and Calvin, to affirm that the covenant of grace is one covenant only. Even McComiskey, who uses the plural in the title of his book (The Covenants of Promise), has only moved half way from this position, by arguing that alongside the one permanent covenant of grace there are different 'administrative covenants', as he calls them, at different eras. It is true that the different covenants overlap, so that, for example, the covenant promises to Abraham and to David are ultimately fulfilled in Christ, as the New Testament teaches, but this does not make the covenants identical. The three covenants with Israel in the wilderness are indeed the same in substance, being based upon the terms of the Mosaic Law; but they differ from the covenants with Noah, Abraham and David, and from the New Covenant (which would not otherwise be 'new'), even though they may be quite consistent with those covenants. It is true, as Calvin points out (Institutes 2:10:8f.), that from the covenant with Abraham onwards, God does speak in several of his covenants of his being 'God to' Israel and of Israel being 'his people' (Gn. 17:7f.; Dt. 29:13; Je. 31:33), but this phraseology does not occur in all God's covenants, and though its connotation is certainly that of a gracious relationship, it is also of an otherwise unspecific relationship, with himself. To speak of it as the whole substance of those covenants, when they have so much in them that is more specific, is an exaggeration. So we shall continue in this paper, as we have begun, by distinguishing God's various covenants from each other. In doing so we shall not, of course, ignore their important points of contact, but will seek to establish their mutual relationship.

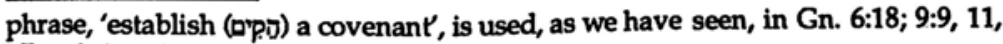
17 and elsewhere. 


\section{THE CONSTITUENTS OF GOD'S COVENANTS}

We saw earlier that a covenant, in the Old Testament, is 'a league of friendship, either between man and man or between God and man, solemnly inaugurated, either by words alone or by words and symbolical ceremonies, in which obligations are undertaken on one or both sides. The obligations are often accompanied by an oath, and have the character of solemn promises.' Examples of the oaths often accompanying human covenants are Gn. 21:23f., 31; 26:28; 31:53; I Sa. 20:17; Ezk. 17:13, 18; Ho. 10:4, and the symbolical ceremonies by which they are often inaugurated are strikingly varied. One party may give the other a present (as Abraham does to Abimelech - Gn. 21:27, and Jonathan to David - I Sa. 18:4), or one party may make a feast for the other (as Isaac does for Abimelech - Gn. 26:30), or, more solemnly, one party may offer sacrifice and invite the other to eat of the sacrifice (as Jacob does for Laban - Gn. 31:54), or one or both parties may raise memorials (as Jacob and Laban do - Gn. 31:44-53, and as Joshua does - Jos. 24:26f.), or they may offer sacrifice and pass between the parts (as Zedekiah and the men of Jerusalem do - Je. 34:18f.).

All this is true of God's covenants also. They are solemnly inaugurated, either by words alone, as in the case of the covenant with David (2 Sa. 7:8-17), ${ }^{26}$ the covenants with Aaron and Phinehas, and the second and third of the covenants with Israel in the wilderness; or else by sacrifice, which is obviously the most appropriate ceremony when one of the parties to the covenant is God. Again, his covenants are often accompanied by oaths (Dt. 7:12; 29:12, 14; Pss. 89:3, 34f., 49; 132:11f.; Ezk. 16:8). It is because of the solemnity of the undertakings in covenants that God's covenants are to be 'remembered', not 'forgotten' (Gn. 9:15; Ex. 2:24; 6:5; Lv. 26:42, 45; Dt. 4:23, 31), 'kept', not 'broken' or 'transgressed' or 'forsaken' (Gn. 17:9f., 14; Ex. 19:5; Lv. 26:15, 44; Dt. 7:9, 12; 17:2; 29:9, 25; 31:16, 20; 33:9; Jos. 7:11, 15; 23:16; Jdg. 2:1, 20; 1 Ki. 19:10, 14; 2 Ki. 18:12; Pss. 55:20; 89:34; Is. 24:5; 33:8; Je. 31:32; 34:18; Ezk. 44:7; Ho. 6:7; 8:1; Zc. 11:10). Otherwise the curses of the

26 Only called a covenant elsewhere, but with great frequency, and on the first occasion by David Himself (2 Sa. 23:5; 2 Ch. 13:5; Pss. 89:3, 28, 34; 132:11f.; Je. 33:21f.). Even in 2 Sa. 7, the term Tp (probably meaning 'faithful covenantkindness') is used in v. 15 . 
covenant' will be incurred, and 'the vengeance of the covenant' will be executed upon the offender (Lv. 26:25; Dt. 29:21).

God's own frequently spoken of in connection with his covenants (Ex. 34:6f.; Dt. 7:9, 12; 2 Sa. 7:15; 1 Ki. 8:23; 2 Ch. 6:14, 42; Ne. 1:5; 9:32; Pss. 25:10; 89:1f., 24, 28, 33, 49; 103:17; 106:45; Is. 54:8, 10; 55:3; Dn. 9:4; Ho. 6:6; Mi. 7:20). ${ }^{27}$ The undertakings from God's side (his promises) are signally gracious, not only because they are so great but also because they are wholly undeserved, and are often made with the offences of the other party fully in view (Gn. 8:21; Ex. 34: 6-9; Dt. 31:14-29; 2 Sa. 7:14f.; Je. 31:32, 34). Since the parties in God's covenants are not equals, and God is always the sovereign initiator of the relationship, the undertakings from man's side are to carry out what God prescribes. From this point of view, 'covenant' means a covenant-law (Gn. 17:10, 13; Ex. 31:16f.; 34:28; Lv. 24:8; Dt. 4:13; 5:2ff.; 9:9, 11, 15) which God 'commands' (Jos. 7:11; 23:16).

One feature of God's covenants which has no close parallel in human covenants is the repeatable covenant 'sign' or 'token', of which more will be said below. The nearest parallel in human covenants is the giving of a present ( $\mathrm{Gn}$. 21:27; I Sa. 18:4) or the raising of a memorial (Gn. 31:44-53; Jos. 24:26f.), which, though it is part of the inauguration of the covenant, serves also as a permanent reminder.

\section{A COMPARISON OF GOD'S COVENANTS}

A broad comparison of God's covenants with each other shows many important resemblances, but also many differences. First, they all result from the sovereign initiative of God. As Dumbrell points out, ${ }^{28}$ he makes them with men with whom he already has a gracious relationship; and he occasionally makes them in response to an expression of faithfulness on their part (such as Phinehas's jealousy for the Lord or David's desire to build him a house); but even then it is an unanticipated response of a signally gracious kind. ${ }^{29}$

27 For the use of the term 700 in relation to human covenants, see Gn. 21:23; 1 $\mathrm{Sa}$. 20:8, 14f.; $1 \mathrm{Ki}$. 20:31. In the LXX it is translated Exeos (mercy), and it is usually rendered 'mercy' or 'ovingkindness' in the English Bible.

28 Covenant and Creation 19, 78 etc.

29 This may not be so obvious in the case of Phinehas, but in fact the Zadokite high priesthood, which replaced the family of Eli in the time of Solomon and continued until the second century $B C$, was descended from Phinehas (1 Ch. 6:1- 
Secondly, they all include promises, though different promises (see the Table opposite for this and subsequent points): regular seasons, uninterrupted by the devastation of a future universal deluge (covenant with Noah); a seed and a land (covenant with Abraham); to be a unique treasure to God, a kingdom of priests and a holy nation (covenant with Israel at Sinai); ${ }^{30}$ a perpetual priesthood (covenant with Phinehas); the priestly perquisites (covenant with Aaron); permanent possession of the throne for his family (covenant with David); forgiveness, the knowledge of God and the Law written upon the heart (New Covenant).

Thirdly, they nearly all include commands: capital punishment for murder, and abstention from eating blood (covenant with Noah), ${ }^{31}$ or circumcision (covenant with Abraham), or the Mosaic Law; embracing all these and much more, and centring on the Ten Commandments (covenant of Sinai), ${ }^{32}$ or the Mosaic laws of cleanness and redemption of the firstborn (covenant with Aaron), ${ }^{33}$ or the Mosaic Law in general (covenant with David), ${ }^{34}$ or the Law written on the heart (New Covenant). Only the covenant with Phinehas contains no commands, and so is purely a covenant of promise; but in the covenant with Abraham, where the only express command is circumcision, the emphasis is certainly on the promises. Conversely, in the Sinai covenant, where the Law is elaborate

15), and so was the Maccabean high priesthood which succeeded it (1 Macc. 2:54). 30 Ex. 19:5f., where the making of the covenant in Ex. 24 is announced in advance. Cf. also Dt. 28:9.

31 This assumes that the sacrifice is the ceremony inaugurating the covenant with Noah, like the sacrifice in Ex. 24 and the sacred rite (not actually called a sacrifice) in $\mathrm{Gn}$. 15. If so; the commands that come between the sacrifice and the covenant promise to Noah are inescapably covenant commands, and the common statement that the covenant with Noah is purely a covenant of promise needs correction. As regards the obligation today of the second of these commands, abstention from eating blood, it is usually assumed that, since the time when Jesus abolished the literal observance of food laws (Mk. 7:19), the prohibition of eating blood is fulfilled by showing respect for God's gift of life, and that the temporary continuance of the regulation in Acts 15:19-21 was out of consideration for Jewish Christians who at that time still continued the literal observance of the Law.

32 The Ten commandments are often called 'the covenant', i.e. the covenant-law (Ex. 34:28; Dt. 4:13; 5:2ff; 9:9, 11, 15). Cf. also $1 \mathrm{Ki}$. 8:9; $2 \mathrm{Ch}$. 5:10, and the regular title 'ark of the covenant' for the chest containing the tables of the Ten Commandments.

$33 \mathrm{Nu}$. 18:11, 13, $15-17$.

34 Ps. 89: 30-3; cf. 2 Sa. 7:14f.; 1 Ki. 2:3f. 


\begin{tabular}{|c|c|c|c|c|c|c|}
\hline Covenant & Promises & Commands & $\begin{array}{l}\text { Divine } \\
\text { Oaths }\end{array}$ & Sacrifice & 'Sign' & Parties \\
\hline $\begin{array}{l}\text { with } \\
\text { Noah }\end{array}$ & $\begin{array}{l}\text { regular } \\
\text { seasons; } \\
\text { no future } \\
\text { universal } \\
\text { deluge }\end{array}$ & $\begin{array}{l}\text { capital } \\
\text { punishment } \\
\text { for murder; } \\
\text { abstention } \\
\text { from eating } \\
\text { blood }\end{array}$ & none & (probably) & rainbow & $\begin{array}{l}\text { Noah } \\
\text { and } \\
\text { whole } \\
\text { crea- } \\
\text { tion }\end{array}$ \\
\hline $\begin{array}{l}\text { with } \\
\text { Abraham }\end{array}$ & $\begin{array}{l}\text { a seed } \\
\text { and } a \\
\text { land }\end{array}$ & circumsion & yes & yes & $\begin{array}{l}\text { circum- } \\
\text { cision }\end{array}$ & $\begin{array}{l}\text { Abraham } \\
\text { and his } \\
\text { seed }\end{array}$ \\
\hline at Sinai & $\begin{array}{l}\text { to be a unique } \\
\text { treasure } \\
\text { to God, a } \\
\text { kingdom of } \\
\text { priests and a } \\
\text { holy nation }\end{array}$ & $\begin{array}{l}\text { Mosaic } \\
\text { laws centred } \\
\text { on the ten } \\
\text { command- } \\
\text { ments }\end{array}$ & & yes & sabbath & Israel \\
\hline $\begin{array}{l}\text { with } \\
\text { Phinehas }\end{array}$ & $\begin{array}{l}\text { a per- } \\
\text { petual } \\
\text { priesthood }\end{array}$ & none & & none & none & $\begin{array}{l}\text { Phinehas } \\
\text { and his } \\
\text { family }\end{array}$ \\
\hline $\begin{array}{l}\text { with } \\
\text { Aaron }\end{array}$ & $\begin{array}{l}\text { the } \\
\text { priestly } \\
\text { perquisi- } \\
\text { tes }\end{array}$ & $\begin{array}{l}\text { Mosaic laws } \\
\text { of clean- } \\
\text { ness and } \\
\text { redemption } \\
\text { of the first- } \\
\text { born }\end{array}$ & & none & none & $\begin{array}{l}\text { Aaron } \\
\text { and his } \\
\text { family }\end{array}$ \\
\hline $\begin{array}{l}\text { with } \\
\text { David }\end{array}$ & $\begin{array}{l}\text { permanent } \\
\text { possession } \\
\text { of the } \\
\text { throne for } \\
\text { his family }\end{array}$ & $\begin{array}{l}\text { Mosaic laws } \\
\text { in } \\
\text { general }\end{array}$ & yes & none & none & $\begin{array}{l}\text { David } \\
\text { and his } \\
\text { family }\end{array}$ \\
\hline New & $\begin{array}{l}\text { the know- } \\
\text { ledge of God } \\
\text { and the } \\
\text { Law written } \\
\text { upon the } \\
\text { heart }\end{array}$ & $\begin{array}{l}\text { law } \\
\text { written } \\
\text { on the } \\
\text { heart }\end{array}$ & & yes & $\begin{array}{l}\text { baptism; } \\
\text { Lord's } \\
\text { Supper; } \\
\text { Lord's } \\
\text { Day }\end{array}$ & $\begin{array}{l}\text { 'the } \\
\text { house } \\
\text { of Israel } \\
\text { and the } \\
\text { house } \\
\text { of Judah' }\end{array}$ \\
\hline
\end{tabular}


and the promises conditional, ${ }^{35}$ the emphasis is on the commands. Fourthly, two or three of the covenants (the covenant with David, one of the covenants with Israel, and seemingly the covenant with Abraham) ${ }^{36}$ are accompanied by oaths on God's part.

Fifthly, two or three of the covenants are inaugurated by animal sacrifice, or a similar rite (the covenant with Noah, probably, the covenant with Abraham, ${ }^{37}$ and the Sinai covenant); and the New Covenant is inaugurated by the substance of sacrifice, no longer a mere symbolical ceremony that is to say, by the sacrifice of Christ, who spoke in this connection of 'my blood of the covenant' or 'the new covenant in my blood' (Mk. 14:24; 1 Cor. 11:25).

Sixthly, several of the covenants have an outward 'sign' or 'token' (Heb. tis ), not to inaugurate it but to maintain it generation after generation. The covenant with Noah has the rainbow (Gn. 9:14-17), the covenant with Abraham circumcision (Gn. 17:9f., 13f.), the covenant of Sinai the sabbath (Ex. 31:13, 16f.; cf. Is. 56:4, 6; Ezk. 20:12, 20), and the New Covenant, so Reformed theology maintains, has the two sacraments. Though the Septuagint equivalent of the term 'sign' or 'token' (onpeíov) is not used in the New Testament in this connection, the sacrament of baptism has taken the place of circumcision as the Christian initiation ceremony, and the sacrament of the Lord's Supper actually contains, as part of the instituted rite, Christ's words about his covenant blood, quoted above. By parity of reasoning, it could be argued that the sabbath has been replaced as a 'sign' or 'token' by the Lord's Day ${ }^{38}$.

35 Ex. 19:5; cf. Dt. 30: 15-20.

36 Pss. 89:3, 34f., 49; 132:11f. (David); Dt. 29:12, 14; cf. Ezk. 16:8 (Israel); Dt. 7:12; cf. Gn. 22:16-18; Lk. 1:72f. (Abraham).

37 Sacrificial language is not used in $\mathrm{Gn}$. 15, but (as the commentators point out) the covenant ceremony there has important points in common with the later law of sacrifice. The ceremony is commanded by God; the animals prescribed are all clean ones; and though the beasts are divided, the birds are not. In the ceremony, God passes between the parts of the divided beasts, as in the human covenant of Je. 34:18f. This extraordinary act of condescension on God's part is usually thought to be a malediction on the covenantor if he proves unfaithful. For a parallel ceremony in a vassal-treaty, and its interpretation, see D. J. McCarthy, Treaty and Covenant 91-105. The common phrase 'cut a covenant' may have arisen from some such ceremony. Another human parallel is the verbal selfmalediction used by Jonathan in one of his covenants with David (1 Sa. 20:13).

38 See also R. T. Beckwith and W. Stott, This is the Day (London, Marshall, 
Seventhly and lastly, it should be noted that the parties to God's covenants are sometimes, but not always, the same. The covenant with Noah is made not with Noah alone but with the whole human and animal creation; the covenants with Aaron, Phinehas and David are made with particular families within Israel; but three of the covenants are made with Israel as such, and the same is really true of the covenant made with Abraham and his seed. The New Covenant, likewise, is made with 'the house of Israel and the house of Judah' (Je. 31:31), and not with any new people - though doubtless with the faithful remnant of Israel and Judah, among whom (as Paul explains in Romans 11) great numbers of believing Gentiles have now been grafted in.

\section{THE INTERRELATION OF GOD'S COVENANTS}

The covenant with Noah, being made not only with Noah but with the whole creation, provided a context within which the covenants with his chosen people (with Abraham and with Israel) could be made; and the covenants with Israel provided a context within which the covenants with the house of Aaron, the house of Phinehas and the house of David could be made. The order in which the covenants were made (according to the biblical account) is therefore fully intelligible.

Even God's New Covenant with his people was made within the context of his covenant with the whole creation (the covenant with Noah), which will only be superseded with the coming of the new creation, when all things will be summed up in Christ (Eph. 1:10). The covenants with the house of Aaron and the house of Phinehas were superseded at Christ's first coming, however, when his own eternal priesthood replaced the Levitical priesthood (Heb. 7:11-28). The covenant with the house of David continued, meanwhile, its promises being fulfilled in the everlasting kingship of the Son of David (Lk. 1:32f.).

Thus far, the interrelation between God's covenants is not difficult to see, and they all point forward to Christ. The interrelation between God's different covenants with his people, however, is less simple. How are the covenants with Abraham and his seed, the Mosaic covenants (which for this purpose may be considered together, their substance being the same) and the Morgan \& Scott 1978) esp. 13, 34f. 
New Covenant interrelated? Are they all spiritual in their character? Are they all covenants of grace? Are they all made with the same people? Do they all look forward to Christ? The remainder of this paper must be devoted to these issues.

Each of God's covenants with his people, as we have seen, has involved ceremonial observances. But there has always been another side. Even the Mosaic covenants, in which ceremonies bulked so large, demanded an obedience not only ceremonial but moral. And the covenant with Abraham and the patriarchs, whereby God solemnly confirmed to them his promises and oaths, is certainly not more purely external than the Mosaic covenants. The attempts made to interpret it in mere external terms are failures. As seen by the New Testament writers, the Old Testament account of it absolutely demands the spiritual interpretation which they give.

It is true that this covenant had an external rite; but external rites do not necessarily mean a purely external covenant. It is true that the number of Abraham's literal seed was a fulfilment of a covenant promise to him (compare Ex. 32:13f.; Dt. 1:10; 10:22; with Gn. 15:5; 22:17; 26:4); and that a literal land was promised (Gn. 13:14f.; 15:7, 18-21; 17:8; 24:7; 26:3f.; 28:13; 35:12; 48:4), to be enjoyed after the Exodus ( $\mathrm{Gn}$. $15: 14,16 ; 46: 4 ; 50: 24)$. But both these literal promises belonged to the faithful. A numerous literal seed was a promise to faithful Abraham, and only incidentally to that numerous literal seed. And the same is true of the land. It was promised to faithful Abraham, and though it was received and for a long time enjoyed by Abraham's seed despite their prevailing ungodliness (Ex. 32:9-14; Dt. 9:4-6; 2 Ki. 13:23; Ezk. 20:5-22), yet by right of the promise the land belonged to them only as long as they followed the Lord (Lv. 26:41f.; Dt. 6:10-15; 8:1; 11:8f., 18-25; 19:8f.; 30:19f). Moreover, as the writer to the Hebrews points out, the confession of the patriarchs that they are strangers and pilgrims (Gn. 23:4; 47:9) shows that they were not looking simply for an earthly land (Heb. 11:9f., 13-16). This is particularly plain when the statement is made with regard to the time after the entry of their descendants into Canaan (Lv. 25:23; 1 Ch. 29:15; Pss. 39:12; 119:19).

With the other promises it is still clearer that they belong only to the faithful. The promise in Genesis that all the families 
of the earth would be blessed in Abraham and his seed (Gn. 12:2f.; 18:18; 22:18; 26:4; 28:14) cannot on this interpretation, which is also that of the Septuagint, ${ }^{39}$ Ecclesiasticus ${ }^{40}$ and the New Testament, ${ }^{41}$ mean anything other than the blessings of the gospel. ${ }^{42}$ The promise that many nations and kings will spring from Abraham (Gn. 17:4-6) is to be fulfilled through Sarah (Gn. 17:16), thus excluding the Ishmaelites and Midianites, and through Jacob (Gn. 35:11; 48:4), thus excluding the Edomites and with them the external interpretation! The covenant itself is made with Abraham on the basis of his justifying faith and acts of faith (Gn. 15:6-21; 22:16-18; 26:3-5; Ne. 9:8) and the covenant promises belong to his descendants only in so far as they here follow his example (Gn. 18:19; Dt. 4:30f.; 7:12f.; 13:17f.; Is. 58:13f.).

Finally, Paul points out in Romans 9 that this covenant and its promises did not come to nothing when most of the Jews rejected Christ, for it was not made with them all, but only with the elect among them. Paul does not here ignore the fact that Israel was elected as a nation, to which the wicked as well as the righteous belong (Ezk. 20:5; Am. 3:2), or that this choice of Israel is irrevocable (Je. $31: 35-7 ; 33: 23-6)$. Far from it, he goes on in chapter 11 to stress these two facts himself, the first in verse 28 and the second in verses 1-2, 29; and they are indeed implied in chapter 9 itself, the first in verses 1-5 and the second in verse 6 . On the other hand, he is equally aware of the facts (at first sight inconsistent with these) that God demands obedience from Israel as a condition of remaining his special people (Ex. 19:5; Dt.

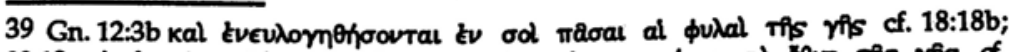
22:18 kal Eveviopण

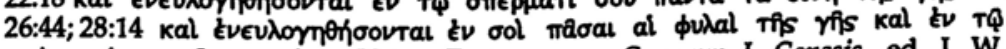

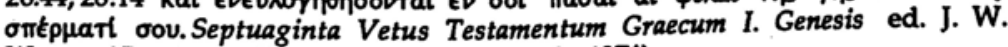
Wevers (Göttingen, Vandenhoeck \& Ruprecht 1974).

40 Eoclus. 44:21

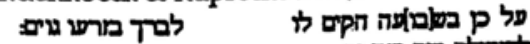

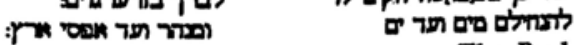

The Historical Dictionary of the Hebrew Language. The Book of Ben Sira. Jerusalem, Keter Press 1973) 54. The Greek translator of this passage may have been influenced by the LXX of Genesis; see above.

41 There are direct citations of $\mathrm{Gn} .12: 3 / 18: 18$ at Gal. 3:8 and of Gn. 22:18/26:4 at Acts 3:25.

42 Modern commentators on Gensis often favour the translation bless themselves' instead of 'be blessed' (e.g. E. A. Speiser, Genesis [AB; New York, Doubleday 1964] 86; G. von Rad, Genesis [ET; London, SCM 1972] 160; C. Westermann, Genesis 12-36 [ET; Minneapolis, Augsburg 1985] 151-2), but even this may imply that the blessing which the nations invoke upon themselves is granted. 
26:18), and that in view of their sins he has determined to pour judgement upon the nation until only a righteous remnant remains (1 Ki. 19:18; Is. 10:20-2; 17:4-7; cf. Rom. 9:27-9; 11:2-5). Combining these two sorts of teaching, Paul infers that the nation was elected only for the sake of those faithful members whom it would include (Rom. 11), who may therefore themselves, in contradistinction from the rest, be spoken of as God's elect (11:5, 7; cf. Is. 65:9, 15, 22, in context), and in whom his election of the nation is indeed never revoked (11:1-5, 25-32). In Romans 9 Paul explains the teaching of the Old Testament in the same way. There is an election within Israel (v. 11), and it is in the chosen group that the election of the nation takes effect ( $v$. 6).

When the covenant with Abraham is considered in this light, one can see the significance of the fact that, though Ishmael was Abraham's son, and received the token of the covenant (as did all his descendants apparently down to the time of our Lord, see Josephus, Antiquities 1:12:2, or 1:214), yet at the very institution of circumcision it was declared that with Isaac and not Ishmael should God establish his covenant (Gn. 17:18-21), and later that in Isaac and not Ishmael should Abraham's 'seed' be called (Gn. 21:12). So also Esau was Isaac's son, and presumably was circumcised, yet God's rejection of him and acceptance of Jacob (Mal. 1:2f.) was indicated even from the womb (Gn. 25:23). All are not Abraham who are of Abraham, all are not Isaac who are of Isaac, Paul points out; and concludes that all are not Israel who are of Israel (Jacob), so that God's promises have indeed been fulfilled, in no other way than that in which they were intended from the beginning, that is, they have been fulfilled 'acording to election', to those within Israel who were truly the chosen of God (Rom. 9:6-13).

According to the Old Testament itself, therefore, the promised land is in one sense earthly, but in another heavenly, and even in the earthly sense belongs only to the faithful. Likewise, according to the Old Testament, Abraham's seed is in one sense his natural seed, but in another the elect and believing from among his natural seed, and God's promises belong to the latter, and to Abraham, to whom the natural seed is given. As to his parentage of many nations, the Old Testament, without interpreting the phrase, certainly excludes a natural parentage. 
And since the Old Testament teaches that believers within Israel are in a special sense Abraham's seed, presumably those among the nations whom it reckons his seed are likewise the believers (as is taught, of course, by the New Testament in Rom. 4:13-17). This fact interprets also the promise, incapable of an external interpretation, that in him and in his seed should all nations be blessed: that is, the blessing of God (the gift of the Spirit) is for those among them who, like Abraham and his true seed, are justified by faith (as is taught by the New Testament in Gal. 3:2, $5-9,14)$.

The New Testament conception of believers as Israel (Mt. 19.28; Lk. 22:30; Jn. 1:47; Rom. 9:6; 1 Cor. 10:18; Gal. 6:16; Phil. 3:3; Rev. 7:1-8; 21:12), and the New Testament notion of Abraham's seed as those who, irrespective of descent, share his character (Jn. 8:33, 37-44; Rom. 4:11f., 16; Gal. 3:7; cf. Mt. 3:8f.; 1 Pet. 3:6) and his privileges (Gal. 3:29; Heb. 2:16), are therefore not spiritualizations of literal Old Testament ideas, but direct inferences from the spiritual teaching of the Old Testament. If the promise that they should possess the gate of their enemies (Gn. 22:17) is also spiritualized by the New Testament (Lk. 1:725), this is only because the Old Testament itself demands a spiritual interpretation for the other promises. If Abraham is said by the New Testament, without explicit Old Testament authority, to be heir of the world (Rom. 4:13), this is not without Jewish precedent (Ecclus. 44:21, see note 40), and is in the New Testament simply a way of expressing the world-wide conquests of the gospel which the promises to Abraham do teach. And if the New Testament surprises us by identifying the seed of Abraham with Christ (Acts 3:25f.; Gal. 3:16), it explains this identification: Christ is the seed of Abraham not only as being, of course, the chief of his literal seed, but as being him in whom believers (Abraham's spiritual seed) are all one (Gal. 3:28f.).

Such then was the covenant with Abraham and his seed, according to both the Old Testament and the New. It stood in election and faith on the one hand, in an external rite on the other. When God made another covenant with Abraham's seed, through Moses, it did not abrogate the former (Ex. 32:13f.; Lv. 26:42; Dt. 29:12f.; Gal. 3:17-24), and this was signalled by the fact that circumcision was retained as the rite of entry into the covenant relationship. The external rites were multiplied under 
this second covenant, the observance of the sabbath being singled out in particular (Ex. 31:13, 16f.); the promises were made more explicit (especially by the prophets of this period), as regards the blessing of all nations, the gift of God's Spirit, and the One in whom the promises were bound up; and a detailed law was imposed. The last is an apparent innovation, but since the former covenant remained in force, it was clearly not intended to change the relationship between God and his people, who were therefore to 'seek the law by faith' (Rom. 9:31f.), as regards both its ritual and its moral requirements. The faith required by the covenant with Abraham had been no mere intellectual faith but the faith that works through love (Gn. 18:19; 22:16-18; 26:3-5; Dt. 4:30f.; 7:12f.; 13:17f.; Is. 58:13f.; Heb. 11:8f., 17-19; Jas. 2:21-4), and it therefore did not annul but more firmly establish that covenant when believers gained the fuller knowledge, which the Law gave, of how to exercise their faith in obedience.

It is true that the Law is often represented in Scripture as a covenant of works (Lv. 18:5; Dt. 27:26; Ne. 9:29; Je. 11:3-5; Ezk. 18:4, 20; 20:11, 13, 21; Rom. 10:5f.; Gal. 3:10-12; Jas. 2:10f.), but these statements must not be taken in isolation from those in which the Law preaches God's mercy and the forgiveness of sins, from the rites of atonement which the Law institutes, and from the very basis of the Law, the gracious and unmerited deliverance of the people from Egypt. When, therefore, Scripture represents the Law as a covenant of works, it must be understood in some such sense as the following: that the Law is a revelation of God's will, so perfect that anyone who completely fulfilled it would be justified (Gal. 3:21), and so binding that anyone who transgresses it, unless he takes advantage of God's mercy, will fall under his wrath (Rom. 2:12; 3:19; 4:15; 2 Cor. 3:7, 9; Gal. 3:10). The actual effect of the Law (except in the single case of Christ himself) ${ }^{43}$ was not to justify men by works but to convict them of $\sin$ (Rom. 3:20; 5:20; 7:7f.,

43 Although Christ was original in his interpretation of the Law, he agreed with his opponents that its chief commandments were the love of God and the love of one's neighbour (Mk. 12:28-34), and these were the constant characteristics of his own conduct On. 13:1, 34; 14:31; 15:9, 12-14; Rom. 8:37; 2 Cor. 5:14; Gal. 2:20; Eph. 5:2, 25; 1 Jn. 4:19; Rev. 1:5). He was content that others should judge by the Law whether he was a sinner or not (n. 8:46), and it was because he was spotless by this standard that he was fit to pay the penalty of the Law for others (Heb. 9:14; 1 Pet. 1:19). 
13; Gal. 3:19; I Tim. 1:8-10), and thus not to supersede the covenant of grace but to lead men to consent to it (Gal. 3:23-5). It was a hypothetical covenant of works, but an actual covenant of grace. Inasmuch, then, as the Law is a reaffirmation of the covenant of grace, demanding faith (Dt. 1:32; 9:23; Pss. 78:22, 32; 106:24; Rom. 9:32; Heb. 3:7-4: 13; Jude 5) and summed up in love (Dt. 6:1-5; Je. 7:22-4; Mt. 22:36-40; Rom. 13:8-10; Gal. 5:14), this covenant, like the former, belongs properly to the believing, the converted, the elect among Abraham's descendants, and to noone else among them.

This then is the background against which God has now made yet another covenant with his people, called, by contrast with that of Sinai, the New Covenant (Je. 31:31f.; Lk. 22:20; 1 Cor. 11:25; 2 Cor. 3:6-16; Heb. 8:6-13; 9:15-20; 12:24; cf. Gal. 4:24-6), and has instituted the sacraments of baptism and holy communion and the observance of the Lord's Day for those with whom this covenant is made. It is a background in which God's covenants have been made with the elect, the faithful, but in which he has nevertheless required of them, as indispensable conditions of the covenant relationship, the observance of certain covenant rites. Before asking what light this throws on the New Covenant and its rites, it will be well to inquire whether this is merely a background, that is, whether the New Covenant has abrogated the covenants that preceded it. It is not disputed by anyone that this covenant (like the others) belongs to believers, and is (like the others) a covenant of grace. Its promises are, of course, those of the gospel, and it does not propose these as new promises, but rather claims to inaugurate the fulfilment of those given under the former covenants but as yet unfulfilled - the promises of a Messiah, atonement, the gift of the Spirit, the call of the Gentiles, and the heavenly country.

One fundamental innovation is often attributed to the New Covenant, however: that it is made with a new people - not the believing Jews but the believing Gentiles. This in fact is not so. Admittedly the New Testament sometimes speaks in this fashion, as in Mt. 21:43 and Lk. 13:6-9. But in these passages it is simply generalizing from the fact that the majority of God's people used to be Jews but from now on are Gentiles. Paul uses the same form of speech even in contexts where his concern is to show that it is only a loose way of talking (see Rom. 9:30f., 10:13, 19-21). It is true also - as Roman Catholics and Baptists alike 
point out - that there are passages in the New Testament where the 'church' is spoken of as something new (Mt. 16:18; Eph.

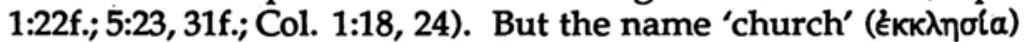
is used in the Septuagint and Acts 7:38 of the congregation of Israel also, and in view of all the facts which we have been considering and are yet to consider in this paper, it is clear that the church can be spoken of as something new only in virtue of its new condition since the coming of Christ, not in virtue of new existence.

It is not accurate, then, to say that the believing Jews used to be God's people, but now the believing Gentiles are. For, first, God's choice of Israel is stated in the Old Testament to be irrevocable (Je. 31 : 35-7; 33:23-6), and the predictions that it makes concerning a further covenant (Is. 42:6; 49:8; 55:3; 61:8; Je. 31:31-4; 32:40; Ezk. 16:60; 34:25; 37:26; Mal. 3:1) represent it as a covenant made with the same people as the covenants that preceded it. ${ }^{44}$ Secondly, the Gentiles were not incapable of becoming members of the covenant people even under the former covenants (Gn. 17:12f.; 34:15-17; Ex. 12:43f., 48f.), and though the nucleus of the covenant people were of Abraham's natural seed, as the Bible stresses (Gn. 15:1-4; Rom. 4:19f.; Heb. 11:17-19), yet it equally stresses that the nucleus of the people of the New Covenant are of Abraham's natural seed (Mt. 10:5f.; 15:24, 26; Jn. 10:16; Acts 2:39; 3:25f.; 13:46; Rom. 1:16; 11:1-32; 15:26f.; Eph. 2:11-15; 1 Thes. 2:14; Rev. 12:1-6, 13-17, and consider the presuppositions of the circumcision controversy), ${ }^{45}$ the only difference being the number of those now adopted in from outside. Even this difference is in principle no innovation, for the seed with whom the covenant of Abraham was made, it was seen above, includes not only those few elect Gentiles who were gathered in during Old Testament times but those many who are being gathered in today.

The covenant people, then, is the same; but the question remains to be answered, Does the New Covenant abrogate the covenants which preceded it? It has already been seen that the covenant of Sinai did not abrogate the covenant with Abraham;

44 Is. 42:6; $49: 8 ; 55: 3$ are somewhat ambiguous on this point, but the rest of the passages concerning the New Covenant are clear enough.

45 I owe this last point to L. Newbigin, The Household of God (London, SCM 1953) 32-6. On the general issue, see P. E. Hughes, The Divine Plan for Jew and Gentile (London, Tyndale Press 1949). 
still less does the New Covenant abrogate it. The Bible emphasizes, it was noted above, that Christians are of Abraham's seed, sharing his justifying faith, enjoying the promise of the Spirit which was spoken to him, and expecting the heavenly country to which he too looked. They are thus living under the covenant with Abraham (Lk. 1:68-75; Acts 3:25f.; Gal. 3:15-29), which the New Covenant therefore does not abrogate. The covenant with Abraham is called 'eternal' (Gn. 17:7, 19; cf. Ps. 105:8-10), and the word is here to be given its unlimited sense. Does the New Covenant abrogate that of Sinai, however? This also, in Is. 24:5, is called 'eternal', and it seems to be viewed as eternal in such passages as Lv. 26:44f. And in so far as the Sinai covenant was a reaffirmation of the covenant with Abraham, in so far as both these covenants were proclamations of the gospel (Gal. 3:8; Heb. 4:2), in so far as both like the New Covenant - pertain only to believers, and the great men of faith, with whom Christian believers claim kinship, belong to both (Heb. 11), in so far as Moses and the prophets who followed him merely made more distinct the promise of the Messiah, in whom all the blessings prepared for the seed of Abraham were bound up (Acts 3:25f.; Gal. 3:16), in so far as Christ came not to destroy the Law but to 'fulfil' it, that is, to reinterpret it in the most comprehensive terms (Mt. 5:17-48; Rom. 8:4; 13:8-10; Gal. 5:14), in so far the New Covenant undoubtedly does not abrogate the Old, and Christians live under the covenant of the Law as truly as under the covenant with Abraham.

The ways in which the Old Covenant has indeed been superseded by the New (Je. 31:31-4; 2 Cor. 3:6-16; Gal. 4:24-31; Heb. 8:6-13; 9:15-28; 10:14-18) and the Law abolished (Rom. 7:4, 6; 8:2; 1 Cor. 6:12; 8:9; 10:23, 29; Gal. 2:4, 19; 5:1, 13, 18; Eph. 2:15) are, first, that under the New Covenant, the Law having done its work, God's people are now ready to accept the apostle's declaration that justification by the works of the Law was never more than a theoretical possibility (Rom. 3:20; Gal. 2:16, 21; 3:11).

Secondly, for those who live under the New Covenant, the Kingdom of God has drawn near, the Messiah has come, the atonement has taken place and the Spirit has been given, that people may repent, believe and be pardoned. Among the ancient Hebrews, conversion, faith and justification existed only 
in anticipation of these events (Rom. 3:25; Heb. 9:15, 25f.), dimly foreseen, but ardently longed for (Lk. 10:23f.; Jn. 8:56; Heb. 11:13; 1 Pet. 1:10-12), and were therefore abnormal and comparatively occasional (Dt. 9:4-6; 29:4; Je. 31:31-4; Acts 7:51-3; 28:25-7; 2 Cor. 3:12-16). They were not unknown (Gn. 15:6; 1 Sa. 13:14; 2 Ki. 23:25; Rom. 4: Heb. 11), but even those who did enjoy the presence of the Spirit did not enjoy this in its Pentecostal fulness, which was a promise and a new experience even to those who were already Christ's disciples and apostles (Jn. 14: 16-20; 16:7, 12f.; Acts $1: 5,8 ; 2: 1-36$ ). Under the Old Covenant, it was chiefly a privilege of prophets to have the Spirit of the Lord (Nu. 11:29) or to know the Lord (Ex. 33:13; Nu. 12:6; 1 Sa. 3:7), and only under the New Covenant are these prophetic privileges extended to the many (Acts 2:14-21; Heb. 8:6-13). ${ }^{46}$ Apart from the saving work of the Spirit the Old Covenant may therefore undoubtedly be described as 'the letter', 'the ministration of death', 'the ministration of condemnation', 'bondage' (Rom. 2:29; 7:6; 8:15; 2 Cor. 3:6f., 9; Gal. 4:3, 8, 24f.; 5:1; Heb. 2:15): and so might even the covenant with Abraham. In short, the greatest of the promises brought by the former covenants related primarily to the period of the New Covenant, and are now, under that covenant, having their fulfilment.

Thirdly, the promises of both the former covenants have, by their present fulfilment in Christ been wonderfully clarified (2 Cor. 3:12-4:6). Similarly clarified have been the character of the covenanting God, revealed in Christ (Jn. 12:45; 14:7-11; 2 Cor. 4:4, 6; Col. 1:15; Heb. 1:3), and his covenant requirements, now given their Christian re-interpretation.

Fourthly, the fulfilment of the covenant promises in Christ has brought into the open the unbelievers among Israel to an unprecedented degree (Lk. 2:34f.; 10:21; Jn. 9:39-41). Previously, it was known for the worldly (for example the Hellenizers in the Maccabean period) to fall away from God's people, but with the New Covenant great numbers of the religious have done so. In their place, unprecedented numbers

46 The 'all' of Je. 31:34 and Heb. 8:11 possibly means 'people of all classes' (compare the 'all flesh' of Joel 2:28f. and Acts 2:17f.). Then the picture is of prophets vainly exhorting the other classes of society under the Old Covenant, but of a good response from those classes under the New Covenant. If, on the contrary, 'all' means 'every individual', it must refer to the final consummation of the New Covenant rather than its present administration, in which every individual belonging to the church does not know the Lord, as the Epistle to the Hebrews itself points out (Heb. 12:14-17). 
of Gentiles have been converted and incorporated into God's people (see especially Rom. 11:11-32).

Fifthly, the bondage of literal observance of the outward, ceremonial ordinances of the Law, which was a burdensome yoke even to believers (Acts 15:10), and a middle wall of partition hindering the conversion of the Gentiles (Eph. 2: 14f.), has been done away, so that servants have become sons (Gal. 4:1-7). And in token that the former covenants are in these respects superseded, the external rites of both have been replaced by a new ritual, simple and painless - the two sacraments of the New Covenant, and by a new festival - the Lord's Day. The new institutions reproduce the meaning of circumcision, the passover meal and the sabbath, ${ }^{47}$ but transcend that meaning by directly relating it, in each case, to Christ and his saving work. The Lord's Supper speaks of Christ's death, the Lord's Day of his resurrection, and baptism of both.

These changes, however, being accepted on the like terms of faith, are no more an abrogation of what has gone before than were the changes made at Sinai. And if the New Covenant does not abrogate the former covenants, but rather embraces and completes them, all three covenants belong to Christians, and the rites and signs of the New Covenant can be considered as the modern rites and signs of the other two covenants as well. ${ }^{48}$

To sum up the argument: there is one people of God, the elect and believing, who primarily belong to Abraham's natural

47 The new institutions did not immediately replace the old, except among Gentile Christians. Jewish Christians, as long as the temple stood and the breach with the synagogue remained incomplete, seem to have tried to maintain both (see Beckwith and Stott, This is the Day 30-5), which may explain why the New Testament does not directly speak of a replacement of one by the other, although it speaks of the old institutions as obsolete (1 Cor. 7:19; Gal. 5:6; 6:15; Phil. 3:2f.; Col. 2:16f.; Heb. 9:9f.). The passover meal is not described by the Old Testament as a covenant 'sign', like circumcision and the sabbath, but since the neglect of any of the three carried the sanction of being 'cut off from one's people' (Gn. 17:14; Ex. 12:15, 19;31:14; Nu. 9:13), it had the same sort of necessity. The only other Old Testament institution carrying this sanction was the day of atonement (Lv. 23:29f.), which, being completely fulfilled by the atoning work of Christ (Heb. 9:1-10:25), has no Christian institution to replace it.

48 Earlier discussions of the differences between the Old Covenant and the New, which the author has profited from reading, are to be found in Calvin, Institutes 2.11:1-12, and Witsius, Oeconomy 4:11-15. 
seed, but exist also among those who have been incorporated into that seed by adoption. With this people of his, God has made various gracious covenants, centred on the gospel promises. Of these covenants, the last is the culmination, though it rather embraces, completes and fulfils the other two than abrogates them. To these covenants God has attached external rites and signs, of which those now obtaining are baptism, the Lord's Supper and the Lord's Day. 